\title{
Öğretmenlerin Pozitif Psikolojik Sermayelerinin Tükenmişliğe Etkisi
}

\section{Rasim TÖSTEN*, H. İsmail ARSLANTAŞ ** Gülay ŞAHİ****}

Öz: Pozitif psikolojik sermaye, olumsuzluklara odaklanmak yerine bireyin iç dinamiklerini harekete geçirmeyi dolayısıyla içsel bir hareketle sürece yaklaşmayı amaçlayan bir yaklaşımdır. Tükenmişlik ise verimliliği olumsuz etkileyen ve son yıllarda aşırı iş yükü, stres, adaletsizlik ve yönetim sorunlarıyla vs. ortaya çıkan önemli bir olgudur. Mesleki tükenmişlik düzeyinin iyileştirilmesinde öğretmenlerin psikolojik sermaye yeterlikleri önemli görülmektedir. Öğretmenlerin psikolojik sermaye yeterliklerinin arttırılmasının tükenmişliğin düşürülmesine olumlu katkılar sağlayacağı düşünülmektedir. Bu çalışmada, öğretmenlerin pozitif psikolojik sermaye yeterlikleri ile tükenmişlik düzeyleri arasındaki ilişkinin ortaya konulması amaçlanmaktadır. Bu araştırma ilişkisel tarama modelinde olup nicel desenlidir. Araştırmaya 487 öğretmen dâhil edilmiştir. Araştırmada öğretmenlerin görüşlerini almak amacıyla iki ölçek kullanılmıştır. Bu ölçekler; öğretmenlerin tükenmişlik düzeylerini ölçmek amacıyla Maslach ve Jackson (1981) tarafından geliştirilen Ergin (1992) tarafından Türkçeye uyarlanan 'Maslach Tükenmişlik Ölçeği'; öğretmenlerin psikolojik sermaye yeterlikleri için Luthans vd. (2007) tarafından geliştirilen, Çetin ve Basım (2012) tarafından Türkçe'ye uyarlanan 'Pozitif Psikolojik Sermaye Ölçeği'dir. Araştırmada elde edilen verilerin çözümlenmesinde betimsel (tanımlayıcı) istatistikler (frekans, yüzde, aritmetik ortalama, standart sapma) ile korelasyon ve basit regresyon analizleri kullanılmıştır. Analizlerde anlamlılık düzeyi $p<.05$ olarak kabul edilmiştir. Araştırma sonucunda psikolojik sermaye ile

\footnotetext{
*Yrd. Doç. Dr., Siirt Üniversitesi, BESYO, rasimtosten@ hotmail.com, Siirt/ Türkiye

*** Doç. Dr., Siirt Üniversitesi, adaca66@gmail.com, Siirt/ Türkiye

***öğr., Siirt Milli Eğitim Müdürlüğü, Siirt/ Türkiye
} 
http://dx.doi.org/10.23891/efdyyu.2017.28

ISSN:1305-020

tükenmişlik düzeyleri arasında orta düzeyde negatif yönde bir ilişki olduğu, ortaya konulan modelin anlamlı olduğu, psikolojik sermaye bileşenlerinin tükenmişliği \%40 açıkladığı, negatif etkisininin olduğu görülmüştür.

Anahtar Kelimeler: Psikolojik sermaye, tükenmişlik, pozitif psikoloji

\section{The Impact Of Teachers' Positive Psychological Capital On Burnout}

Abstract: Positive psychological capital is an approach that aims to move the internal dynamics of the individual rather than focus on negativity, and therefore approach the process with an internal action. Burnout, on the other hand, has a negative impact on productivity, and in recent years has been associated with excessive workload, stress, injustice, and management problems. Psychological capital adequacy of teachers seems to be important in improving occupational burnout. Increasing psychological capital adequacy of teachers is thought to contribute positively to reducing the burnout. In this study, it is aimed to reveal the relationship between teachers' positive psychological capital adequacy and burnout levels. This research is a relational survey model designed as quantitative. For the research 487 teachers were included in the study group. Two scales were used to get the opinions of the teachers in the research. "The Maslach Burnout Scale", developed by Maslach and Jackson (1981) and adapted to Turkish by Ergin (1992) was used to measure the burnout emotions of teachers. "Positive Psychological Capital Scale" developed by Çetin ve Basım (2012) was used for the measurement of the psychological capital of the teachers. In the analysis of the data obtained in the study, descriptive statistics (frequency, percentage, arithmetic mean, standard deviation), correlation and simple regression analyzes were used. The analysis is 
based on $p<0.05$. As a result of the research, it is seen that there is a moderate negative correlation between psychological capital and burnout, the model revealed is meaningful, the psychological capital components explain $40 \%$ of burnout and has a negative impact on it.

Keywords: Psychological capital, burnout, positive psychology

\section{Giriş}

Sosyal araştırmalarda pozitif psikoloji akımıyla birlikte negatif unsurlara odaklanmak yerine pozitif unsurlara odaklanıldığı görülmektedir. İnsan odaklı örgüt yaklaşımında pozitif örgütsel davranışlar önemsenmekte, güçlendirme, geliştirme, problem çözme, dayanma, iyimser ve umutlu olma gibi pozitif kavramlar öne çıkarılmaktadır. Bu kapsamda pozitif örgütsel davranışların etki alanları incelenmekte, pozitif davranışların güçlendirilmesiyle negatifliğin düşürülmesi amaçlanmaktadır.

\section{Pozitif Psikolojik Sermaye}

Psikologların niteliği ve ilgilendiği konular değişmekle beraber İkinci Dünya Savaşına kadar genel olarak insanların olumsuz, bozulmuş, karanlık, normalin dışında faaliyet gösteren yönleri üzerinde durularak yaşanan sorunlara çözümler üretilmeye çalış1lmıştır. İkinci Dünya Savaşı sonrası dünya genelindeki tükenmişlik, mutsuzluk ve kaygıların açtığı olumsuzluklar psikolojinin gelişmesinde etkili olmuştur. Pozitif psikolojinin ortaya çıkmasıyla beraber bireylerin içinde bulundukları umutsuz, mutsuz, negatif durumlardan çıkmaları ve mutlu 
yaşama ulaşma yolları üzerinde çalışmalara odaklanmaya başlanmıştır (Seligman, 2002; Caprara ve Carvore, 2003).

İkinci Dünya Savaşında psikolojinin öne çıkan amaçları arasında; insanların hastalıklarını iyileştirmek, insanların yaşamlarını daha verimli ve duyumlu hale getirmek, insanların sahip oldukları yeteneklerini ve kabiliyetlerini ortaya çıkarmak ve geliştirmek olarak verilebilir (Seligman ve Csikszentmihalyi, 2000). Seligman 1999 yılında ortaya attığ pozitif psikoloji kavramı (Hefferon ve Boniwell, 2014:4) insanın normal olmayan yönü üzerinde durduğu, aynı zamanda da güçlü ve olumlu yönlerini anlayıp geliştirilmesi gerektiğine dikkat çekmiştir. Böylelikle psikoloji biliminin sadece insanların kusurlu, bozulmuş ya da olumsuz yönleri üzerinde durmasının yeterli olmadığını ifade edilmiş ve pozitif psikoloji kavramı ortaya atılmıştır (Linley ve diğerleri, 2006).

Pozitif psikoloji kavramı; iyi oluş, mutlu oluş, kişinin güçlü yanları gibi kişilerin pozitif özelliklerine odaklanmaktadır (Hefferon ve Boniwell, 2014:2). Örgüt teorilerinde bu özellikler insan sermayesi içerisinde değerlendirilmiştir. Örgütlerin ya da bireylerin sahip oldukları sermaye türleri içinde pozitif psikolojik sermaye, bireyin pozitif psikolojisinin gelişmiş hali olarak tanımlanmaktadır (Luthans ve Youssef,2007). Örgütlerin gelişmelerinde ve rekabet avantajını elde etmelerinde sahip olmaları gereken dikkati çeken psikolojik sermaye kavramı, diğer sermaye türlerinden ayrılmıştır ve 2007 yılında ise kapsamlı bir tanım yapılmıştır (Zhao ve Huo, 2009:36).

Pozitif psikolojik sermaye kavramında, bireylerin kendi kapasiteleri üzerinde düşünmelerini sağlamak amaçlanmaktadır. Psikolojik sermayeyle kişilerin kendilerini 
tanımaları için esasen kim oldukları ve gelecekte ne olmak istedikleri ile ilgili durumlar ortaya konmaya çalışılmaktadır. Böylece psikolojik sermayede amaç insan sermayesinin ( ne biliyorsun?) ve sosyal sermayenin (kimi tanıyorsun?) sorularını aşarak kişinin doğrudan 'kimsin?' ve 'kim olacaksın?’ soruları üzerinde düşünmesini sağlamaktır (Luthans ve diğerleri, 2006:388).

Psikolojik sermaye, bireylerin sahip oldukları olumlu özelliklerin bütününü ifade etmektedir. Kişilik özelliklerinden farklı olarak gelişime açıktır (Erkuş ve Fındıklı, 2013). Tettegah'a (2002) göre bireyin hem özel yaşamında hem de iş yaşamında pozitif duygu, düşünce ve davranışlarını kapsamaktadır. Aynı zamanda bireyin çalışma ortamında işten kaynaklanan olumsuzlukları gidermek ve çalışanların işleri ile ilgili gelişimlerini sağlamak amacıyla kullanılabilecek bir araç olarak da kullanılabileceği belirtilmektedir (Luthans ve diğerleri, 2010; Avey, Luthans ve Jensen, 2009).

Psikolojik sermayenin temelde dört bileşeni vardır. Bunlar; umut, özyeterlilik, iyimserlik ve psikolojik dayanıklılıktır. Tösten (2015) kültürel özellikleri de göz önünde bulundurarak temel bileşenlere iki bileşen (dişadönüklük ve güven) daha ilave etmiştir. Örgütün amaçlarına ulaşabilmek için bu bileşenler geliştirilebilir veya yönetilebilir özellikler taşımaktadırlar (Luthans ve diğerleri, 2004).

\section{Tükenmişlik}

Modern örgütlerde sıkça anılan tükenmişlik uzun zaman önce tanımlanmış ve alan yazınında tartışılan kavramlardan biri haline gelmiştir. Çalışanlarda tükenmişlik kavramı ilk defa 1974 yılında Freudenberger tarafından ortaya atılmıştır. Tükenmişlik kavramının 
temelleri ise Freudenberger'dan (1974) da öncesinde Greene'nin 1961 yılında yayımladığ1 'bir tükenmişlik olayı' adlı kitabında ruhsal açıdan çöküntüye uğramış bir mimarın tüm uğraşlarını bırakıp Afrika'daki ormanlara kaçışını konu edindiği kitabında yer almaktadır. Romanda "tükenmişlik" aşırı derecede bitkinlik ve bireyin işine karşı hissettiği öfke duygusu ve kaybettiği idealizm olarak açıklanmaktadır (akt. Yıldırım ve İçerli, 2010; Sılığ, 2003: 10). Freudenberger'a (1974) göre çalışanların iş ortamında başarısız olmaları, yıpranma, enerji/güç kaybı veya isteklerinin karşılanmaması gibi durumlar sonucunda bireyin iç kaynaklarının olumsuz etkilenmesi tükenme olarak ifade edilmektedir (Yıldırım, 2007:3).

Alan yazınında tükenmișlik kavramı üzerine öne çıkan bir diğer isim Maslach olmuştur. Çeşitli tanımlamalar olmalarına rağmen Maslach tarafından yapılan tanımlama daha fazla kabul görmüş̧tür. Christina Maslach tarafından yapılan tanımlamaya göre tükenmişlik bireylerin işleri gereği yoğun duygusal taleplere maruz kalmaları ve sürekli diğer bireyler ile karşı kalmaları sonucunda çalışanlarda görülen fiziksel bitkinlik, uzun süreli yorgunluk, çaresizlik ve umutsuz duygularına karşılık gelmektedir. Aynı zamanda çalışanların yaptıkları işe karşı, yaşamlarına ve diğer bireylere karşı olumsuz tutumlarına bunun yansıması olarak ifade edilmiştir (Maslach ve Jackson, 1981: 99; Ardıç ve Polatcı, 2008).

Maslach tükenmişlik kavramını; duygusal tükenme, duyarsızlaşma ve düşük kişisel başarıya ilişkin olmak üzere üç boyutta ele almıştır (Ergin, 1992: 143). Duygusal tükenme, bireylerin yaşam ve çalışmaya karşı enerjilerinin azalması olarak ifade edilmektedir. Böyle bir durumda birey duygusal olarak tükendiğini hissetmektedir (Silah, 2005). 
Duyarsızlaşma, duygusal kaynakları tükenen bireylerin çalışma ortamlarında hizmet görürlerken müşterilerini birer nesne olarak görmeleri sonucunda kendilerini müşterilerden uzaklaşmış olarak hissetmeleri olarak ifade edilmiştir (Maslach\& Jackson, 1981). Düşük kişisel başarı, bireylerin başarı ile mevcut problemlerle baş edememeleri ve üstesinden gelememeleri ile kendilerini bu konularda yeterli bulamamaları olarak tanımlanmıştır (Dolunay, 2002: 52).

\section{Pozitif Psikolojik Sermaye Tükenmişlik İlişkisi}

Türkiye'de yapılan öğretmen sorunlarıyla ilgili araştırmalara bakıldığında öğretmenlerin isteksizliği, düşük adanmışlığı ve tükenmişliği önemli bir problem olarak görülmektedir. Göreve yeni başlayan öğretmenler daha idealistken, mesleki kıdemin artmasıyla öğretmenlerin ideallerinin zayıfladığı; mevcut düzenin böyle gideceği ve değişmeyeceği inancı ağır basmaktadır (Ergül, Saygın ve Tösten, 2014). Öğretmenlerin bu gibi olumsuz tutumu benimsemelerinde iyimserlik, umut, dayanıklılık, özyeterlik gibi bileşenlerin etkili olduğu düşünülmektedir. Bu durumun ise mesleki tükenmişliğin artmasında önemli rol oynadığı bu araştırmanın hipotezidir.

Pozitif psikolojik sermaye ile tükenmişlik durumu örgütsel davranışları etkileyen iki önemli faktördür (Peng vd., 2013). Eğitim örgütlerinde öğretmenlerin tükenmişlik düzeyinin iyileştirilmesinde psikolojik sermaye yeterlikleri önemli görülmektedir. Öğretmenlerin psikolojik sermaye yeterliklerinin arttırılmasının tükenmişliğin düşürülmesine olumlu katkılar sağlayacağı düşünülmektedir (Wang vd., 2012). Bu bakımdan öncelikle tükenmişlik ile psikolojik sermaye arasındaki ilişkinin ortaya konulması gerekmektedir. Farklı örgütlerde 
bu iki değişken incelense de (Çetin vd., 2013; Laschinger ve Fida, 2014; Aliyev ve Tunç, 2015) eğitim örgütlerindeki incelemeler yetersiz görülmektedir (Cheung, Tang ve Tang, 2011; Tösten vd., 2014).

$\mathrm{Bu}$ çalışmada, öğretmenlerin pozitif psikolojik sermaye yeterlikleri ile tükenmişlik düzeyleri arasındaki ilişkinin ortaya konulması amaçlanmaktadır. Temel amaç kapsamında aşağıdaki sorulara yanıt aranacaktır:

a) Öğretmenlerin pozitif psikolojik sermayeleri ve mesleki tükenmişlikleri ne düzeydedir?

b) Öğretmenlerin psikolojik sermayeleri ile tükenmişlik düzeyleri arasındaki ilişki nasildir?

c) Öğretmenlerin psikolojik sermayeleri tükenmişliği açıklamakta mıdır?

Yöntem

$\mathrm{Bu}$ araştırma ilişkisel tarama modelinde olup nicel desenlidir. İlişkisel tarama modeli, İki ya da daha fazla değişken arasındaki ilişkileri belirlemek ve neden-sonuç ile ilgili ipuçları elde etmek amacıyla yapılan araştırmalardır (Büyüköztürk ve diğerleri, 2014).

Evren ve Örneklem: $\mathrm{Bu}$ araştırmanın evrenini Batman ili merkezinde görevli öğretmenlerden oluşmaktadır. Bu çerçevede araştırmanın evreni 2015-2016 öğretim yılında Batman il merkezlerinde görev yapan 7843 öğretmenden oluşmaktadır. Araştırmanın evrenini temsil edebilecek örneklemi için bu okullarda görev yapan toplam 500 öğretmene random 
yöntemiyle ölçekler dağıtılmıştır. Tösten'in (2015) Türkiye geneli yapmış olduğu çalışmada okul türünün anlamlı farka yol açmadığı göz önünde bulundurulmuş olup bu araştırmada okul türü ayrımına gidilmemiştir. $\mathrm{Bu}$ durum araştırmanın sınırlıklarından biri olarak kabul edilmektedir. Ölçeklerden 487 tanesi işleme alınmıştır. Araştırmada yer alan katılımcılara ait bilgiler Tablo 1'de verilmiştir.

Tablo 1:Araştırmada Yer Alan Öğretmenlere Ait Kişisel Bilgiler

\begin{tabular}{lccc}
\hline \hline Değiş̧kenler & Alt gruplar & $\mathrm{N}$ & $\%$ \\
\hline \multirow{3}{*}{ Medeni Durum } & Evli & 319 & 65,5 \\
& Bekâr & 168 & 34,5 \\
& Toplam & 487 & 100,0 \\
\hline \multirow{2}{*}{ Öğrenim Durumları } & Lisans & 415 & 85,2 \\
& Lisansüstü & 72 & 14,8 \\
& Toplam & 487 & 100,0 \\
\hline \multirow{3}{*}{ Cinsiyet } & Kadın & 280 & 57,5 \\
& Erkek & 207 & 42,5 \\
& Toplam & 487 & 100,0 \\
\hline \hline
\end{tabular}

Tablo 1'de araştırmaya katılan öğretmenlere ait medeni durum bilgilerine bakıldığında katılımc1 öğretmenlerin \%65,5'inin (N:319) evli ve \%34,5'inin bekâr olduğu görülmüştür. Araştırmaya katılan öğretmenlerin öğrenim durumları bilgilerine bakıldığında; öğretmenlerin \%85,2'sinin (N:415) lisans mezunu ve \%14,8'inin lisansüstü mezunu oldukları belirlenmiştir. Öğretmenlerin çoğunun (\%85,2; N:415) lisans mezunu olmaları dikkate değerdir. Araştırmaya katılan öğretmenlerin cinsiyet bilgilerine bakıldığında katılımcı öğretmenlerin \%57,5'inin (N:280) kadın olduğu ve \%42,5'inin (N:207) erkek olduğu görülmüştür. Cinsiyet bazında yarısından fazlasının (\%57,5; N:280) kadın olması dikkat çekmiştir. 
Veri Toplama Aracı: Araştırmada öğretmenlerin görüşlerini almak amacıyla üç ölçek kullanılmıştır. Kullanılan ölçekler; öğretmenlerin psikolojik sermayelerini ölçmek amacıyla Çetin ve Basım (2012) tarafından Türkçeye uyarlanan Pozitif Psikolojik Sermaye Ölçeği, öğretmenlerin tükenmişlik duygularını ölçmek amacıyla Maslach ve Jackson (1981) geliştirilen Ergin (1992) tarafından Türkçeye uyarlanan Maslach Tükenmişlik Ölçeği kullanılmıştır.

Öğretmenlerin pozitif psikolojik sermayelerini ölçmek amacıyla Luthans ve diğerleri (2007) tarafından geliştirilen ve Çetin ve Basım (2012) tarafından Türkçeye uyarlanan 24 ifadeli 'Psikolojik Sermaye Ölçeği' kullanılmıştır. Ölçekte özyeterlilik, umut, iyimserlik ve dayanıklılık olmak üzere dört boyut vardır. Her boyutta da 6 madde bulunmaktadır. Ölçek 5'li likert tipi ifadelerden oluşmaktadır. Soldan sağa doğru "1- Kesinlikle katılmıyorum”, "2Katılmıyorum", “3- Kararsızım”, “4- Kismen Katılıyorum”, "5- Tamamen katıliyorum" şeklinde sıralanmaktadır. Ölçeğin geçerliliği Çetin ve Basım (2012) tarafından yapılmıştır. Buna göre yapılan doğrulayıcı faktör analizi sonucunda elde edilen ki-kare istatistiğinin serbestlik derecelerine oranı $(\chi 2 / \mathrm{df}) 2.18(\chi 2=399,9 \mathrm{df}=183)$; kök ortalama kare yaklaşım hatası (RMSEA) 0.057; Tucker-Lewis indeks (TLI) değeri 0.91 ve karşılaştırmalı uyum indeks (CFI) değeri ise 0.90 olarak bulunmuştur.

'Maslach Tükenmişlik Ölçeği' Duygusal Tükenme, Duyarsızlaşma, Kişisel Başarısızlık olmak üzere üç boyuttan oluşup 5'li likerttir. Soldan sağa doğru 'hiç Katılmiyorum', 'Katılmiyorum', 'Kararsızım', 'Kısmen kat1liyorum’ ve 'Tamamen katılıyorum' gibi derecelendirilmiştir. 
Maslach Tükenmişlik Ölçeği'nin Cronbach Alpha İç Tutarlılık katsayısı .89; Psikolojik Sermaye Ölçeğinin Cronbach Alpha İç Tutarlılık katsayısı .69 bulunmuştur. Sosyal araştırmalarda $0.60 \leq \alpha<0.80$ oldukça güvenilir ve $0.80 \leq \alpha<1,00$ arası değerler yüksek derecede güvenilir olarak kabul edilmektedir (Can, 2014).

Verilerin Toplanması ve Analizi: Ölçme aracı katılımcılara doğrudan ulaşılarak uygulanmıştır. 500 verinin 487 tanesi işleme alınmıştır. Araştırma elde edilen verilerin çözümlenmesinde betimsel (tanımlayıc1) istatistiksel (frekans, aritmetik ortalama, standart sapma) ile değişkenler arası korelasyon ve basit regresyon analizleri kullanılmıştır. Analizlerde $p<.05$ ve $p<.01$ düzeyi esas alınmıştır. Katılımcıların araştırma sorularına verdikleri puanlamalarının aritmetik ortalama değerlendirilmesinde "1.00-1.79 = Kesinlikle Katılmıyorum”, "1.80 - 2.59 = Katılmıyorum”, “2.60 - 3.39= Kararsızım ”, "3.40 - $4.19=$ Kısmen Katılıyorum ”, “4.20 - 5.00 = Tamamen Katılıyorum ” ölçütleri esas alınmıştır. Korelasyon düzeyi değerlendirilmesinde “0- $\pm 0.10 ”$ ilişki yok, “ $\pm 0.11-0.30 ”$ düşük, “ \pm 0.31 $0.70 ”$ yüksek ve “ \pm 0.71 ve üzeri” çok yükssek ilişski olarak kabul edilmiştir.

\section{Bulgular ve Yorum}

Araştırmanın bu bölümünde öğretmenlerin psikolojik sermayeleri ile tükenmişlik düzeylerini ölçmek, arasındaki ilişkiyi ortaya koymak, psikolojik sermaye algılarının tükenmişliğini etkileyip etkilemediğini ortaya koyan bulgular tablolaştırılarak yorumlanmıştır. Buna göre; Tablo 2'de öğretmenlerin psikolojik sermayelerine ve tükenmişliklerine ait betimsel analiz sonuçları yer almaktadır. 
Tablo 2: Öğretmenlerin Psikolojik Sermayeleri ile Tükenmişliklerine İlişkin Betimsel İstatistik Sonuçları

\begin{tabular}{ccccc}
\hline Değişkenler & ALT BOYUTLAR & $\mathbf{N}$ & $\mathbf{X}$ & SS \\
\hline \multirow{3}{*}{ Psikolojik Sermaye } & İyimserlik & 487 & 3,69 &, 85 \\
& Dayanılılik & 487 & 3,68 & 1,15 \\
\cline { 2 - 5 } & Umut & 487 & 3,72 &, 91 \\
\cline { 2 - 5 } & Özyeterlilik & 487 & 3,90 &, 86 \\
\cline { 2 - 5 } Tükenmişlik Duygusu & Toplam & $\mathbf{4 8 7}$ & $\mathbf{3 , 7 6}$ &, $\mathbf{8 6}$ \\
\cline { 2 - 5 } & Duygusal Tükenmişlik & 487 & 2,11 &, 59 \\
\cline { 2 - 5 } & Duyarsızlaşma & 487 & 1,95 &, 48 \\
\cline { 2 - 5 } & Kişisel Baş.Azal.Duyg. & 487 & 2,02 &, 53 \\
\hline
\end{tabular}

Tablo 2'ye bakıldığında araştırmada yer alan öğretmenlerin tükenmişlik derecelerinin düşük düzeyde $(X=2,04)$ olduğu görülmektedir. Tükenmişlik ölçeğine ait alt boyutlardan "Duygusal Tükenmişlik $(\mathrm{X}=2,11)$ ", "Duyarsızlaşma $(\mathrm{X}=1,95)$ ", "Kişisel Başarıda Azalma Duygusu $(\mathrm{X}=2,02)$ ’ düzeylerinde oldukları görülmektedir. $\mathrm{Bu}$ durumda duygusal Tükenmişlik boyutu düşük düzeyde, duyarsızlaşma boyutu çok düşük ve kişisel başarıda azalma duygusu ise düşük düzeyde oldukları saptanmıştır.

Araştırmada yer alan öğretmenlere ait psikolojik sermayelerinin derecesi $(X=3,76)$ yüksek olarak hesaplanmıştır. Psikolojik sermaye ölçeğinin alt boyutları “Özyeterlilik $(X=3,90)$ ", "İyimserlik $(X=3,69)$ ", "Psikolojik Dayanıklılık $(X=3,68)$ ”, “Umut $(3,72)$ ) olarak hesaplanmıştır. Buna göre özyeterlilik, iyimserlik, psikolojik dayanıklılık ve umut boyutlarının yüksek düzeyde oldukları belirlenmiştir.

Öğretmenlerin pozitif psikolojik sermaye yeterlikleri ile tükenmişlik düzeyleri arasındaki ilişkiyi belirlemek üzere korelasyon testi yapılmıştır. Tablo 3'te yapılan korelasyona dair bulgular yer almaktadır.

Tablo 3: Öğretmenlerin Psikolojik Sermayeleri ile Tükenmişlikleri Arasındaki İlişki 


\begin{tabular}{llcc}
\hline \hline & & Toplam & Tükenmişlik \\
\hline \multirow{2}{*}{ Psikolojik } & $\mathrm{r}$ & 1 &,$- 635^{* *}$ \\
Sermaye & $\mathrm{p}$ & &, 000 \\
& $\mathrm{~N}$ & 487 & 487 \\
& $\mathrm{r}$ &,$- 635^{* *}$ & 1 \\
Tükenmişlik & $\mathrm{p}$ &, 000 & \\
& $\mathrm{~N}$ & 487 & 487 \\
\hline \hline
\end{tabular}

Tablo 3'te öğretmenlerin psikolojik sermayeleri ile tükenmişlikleri arasındaki duruma bakıldığında psikolojik sermayeleri ile tükenmişlikleri arasında negatif yönde orta düzeyde ilişkinin olduğu görülmüştür ( $r=-, 64 ; \mathrm{p}<.01)$. İki değişken arasındaki ilişkinin negatif olması değişkenlerden birine ait ölçümlerin artarken diğerinin azalması olarak yorumlanabilir (Büyüköztürk vd., 2008, 92). Buna göre öğretmenlerin psikolojik sermaye yeterlilikleri arttıkça tükenmişlik düzeylerinin düştüğü söylenebilir.

Öğretmenlerin psikolojik sermayelerinin tükenmişlik düzeylerine etkisini ortaya koymak amacıyla öncelikle basit regresyon analizinin varsayımları incelenmiş (Sykes, 1993), sonrasında basit regresyon analizi yapılmıştır. Varsayımlar için maddelerin çarpıklık ve basıklık değerlerine bakıldığında dağılımın normal olduğu, değişkenler arası korelasyonun .90 altında olması çoklu bağlantının olmadığı, varyansların homojen dağıldığı görülmüştür. Regresyon analizi sonuçları Tablo 4'te verilmiştir:

Table 4: Öğretmenlerin Psikolojik Sermayelerinin Tükenmişlik Düzeylerine Ilişkin Regresyon Analizi Bulguları

\begin{tabular}{lccccc}
\hline Yordayıcı Değişkenler & $\mathbf{R}$ & $\mathbf{R}^{2}$ & $\boldsymbol{\beta}$ & $\mathbf{t}$ & $\mathbf{p}$ \\
\hline İyimserlik &, 60 &, 36 &,- 60 & $-16,63$ & $\mathbf{, 0 0}$ \\
\hline Psikolojik Dayanıklılık &, 56 &, 32 &,- 56 & $-15,05$ & $\mathbf{, 0 0}$ \\
\hline Umut &, 61 &, 38 &,- 61 & $-17,08$ & $\mathbf{, 0 0}$ \\
\hline Özyeterlilik &, 55 &, 30 &,- 55 & $-14,56$ & $\mathbf{, 0 0}$ \\
\hline Psikolojik Sermaye Toplamı &, 64 &, 40 &,- 64 & $-18,18$ & $\mathbf{, 0 0}$
\end{tabular}


$\mathrm{p}<.01 *$

Tablo 4'e bakıldığında öğretmenlerin pozitif psikolojik sermayelerinin tükenmişlik değişkenliğini \%40 açıkladığı ve tükenmişliği yordamak için modele dâhil edilen değişkenlerin modele anlamlı katkı sağladığı görülmüş̧ür $(\mathrm{p}<0,01)$. Bununla birlikte pozitif psikolojik sermayenin bileşenleri arasında en yüksek etkiye sahip bileşenin umut olduğu ve negatif yönde etkilediği görülmektedir $\left(\beta=-.61 ; \mathrm{R}^{2}=.38 ; \mathrm{p} \leq .01\right)$. Sonrasında sirasıyla iyimserliğin, psikolojik dayanıklılığın ve özyeterliliğin etkili olduğu görülmektedir.

\section{Sonuç ve Tartışma}

Öğretmenlerin pozitif psikolojik sermaye yeterlikleri ile tükenmişlik düzeyleri arasındaki ilişkinin incelendiği bu çalışmada; öğretmenlerin pozitif psikolojik sermaye yeterliklerinin yüksek düzeyde, tükenmişlik düzeylerinin ise düşük düzeyde olduğu görülmüştür. İlgili araştırmalara bakıldığında Kaya, Balay ve Demirci'nin (2014) yapmış olduğu çalışmada öğretmenlerin pozitif psikolojik sermayesinin orta düzeyde çıktığı görülmüştür. Tösten'in (2015) Türkiye'de öğretmenlerin pozitif psikolojik sermaye algıları üzerine yapmış olduğu çalışmada da öğretmenlerin pozitif psikolojik sermayelerinin yüksek çıkmış olması bu araştırma bulgularını destekler niteliktedir. Öğretmenlerin pozitif psikolojik sermayelerinin yüksek çıkması bireysel ve örgütsel verimlilik bağlamında avantajlı görülmektedir. Yine öğretmenlerin tükenmişlikleriyle ilgili yapılan araştırmalara bakıldığında Çelikkaleli'nin (2011) yapmış olduğu çalışmada orta düzeyde, Ergül, Saygın ve Tösten'in (2013) de Diyarbakır örnekleminde yapmış olduğu çalışmada tükenmişliğin orta düzeyde 
çıktığı görülmüştür. Öğretmenlerin tükenmişlik düzeyinin düşük çıkması bireysel ve örgütsel verimlilik bağlamında avantajlı görülmektedir.

Öğretmenlerin pozitif psikolojik sermaye yeterlikleri ile tükenmişlik düzeyleri arasındaki ilişkinin yönüne ve düzeyine bakıldığında negatif yönde orta düzeyde bir ilişkinin olduğu görülmüştür. Ali ve Ali'nin (2014) Pakistan'da hemşireler üzerinde yaptığı bir çalışmada benzer olarak pozitif psikolojik sermayenin tükenmişlikle negatif yönde korelasyonunun olduğu; Lin'in (2013) turizm sektöründe yaptığı çalışmada; yine Yang, Yeh, Yang ve Mui’nin (2013) beden eğitimi ve spor yüksekokulu öğrencileri üzerinde yaptığı çalışmada öğrencilerin psikolojik sermayeleri ile tükenmişlikleri arasında negatif yönde orta düzeyde ilişkinin olduğu görülmüştür. Herbert'ın (2011) psikolojik sermaye ile tükenmişlik ile ilgili doktora bitirme tezinde aynı şekilde negatif ilişkinin ortaya konulduğu, psikolojik sermayenin arttırılmasıyla birlikte tükenmişlik düzeyinin düşebileceği belirtilmiştir. Gillert'in (2014) doktora tezinde benzeri bir sonuç ortaya çıkmıştır. Bu durumda farklı örneklem gruplarında dahi pozitif psikolojik sermaye ile tükenmişlik arasında negatif ilişkinin olduğu, psikolojik sermayenin arttırılmasıyla tükenmişliğin düşürülebileceği söylenebilir.

Öğretmenlerin pozitif psikolojik sermaye yeterliklerinin tükenmişlik düzeylerini yordayıp yormadığına bakıldığında modelin anlamlı olduğu, psikolojik sermayenin tükenmişliği \%40 olarak açıkladığı görülmüştür. Psikolojik sermayenin bileşenlerin en yüksek etkiye sırasıyla umut, iyimserlik, psikolojik dayanıklılık ve özyeterlik olduğu görülmüştür.Yurtdışında yapılan ilgili araştırmalara bakıldığında Gillert'in (2014), Herbert'in 
(2011), Lin'in (2013), Yang ve diğerlerinin (2013), Ali ve Ali'nin (2014) benzer sonuçlar aldığı, psikolojik sermayenin tükenmişliği açıkladığg ve modelin anlamlı olduğu görülmüştür.

Sonuç olarak pozitif psikolojik sermaye ile tükenmişlik düzeyi arasında negatif yönlü bir ilişkinin olduğu, pozitif psikolojik sermaye tükenmişliği etkilediği, pozitif psikolojik sermayenin arttırılmasıyla tükenmişlik düzeyinin düşeceği söylenebilir.

\section{Makalenin Bilimdeki Konumu (Yeri)}

Eğitim Bilimleri Bölümü/ Eğitim Yönetimi Teftişi Planlaması ve Ekonomisi Anabilim Dal1

\section{Makalenin Bilim Özgünlüğü}

“Pozitif psikoloji” kavramı ilk olarak Martin Seligman tarafından 1999 yılında ortaya atılmış olup Fred Luthans (2002) tarafından "pozitif psikolojik sermaye" kavramı yönetim alanına girmiştir. Türkiye'de pozitif psikolojik sermaye ile ilgili araştırmalar ilk olarak işletme alanında 2010 yılında ortaya konmuş, eğitim örgütlerinde çok daha yakın zamanda çalışılmıştır. Pozitif psikolojik sermaye ile ilgili olabilecek farklı değişkenler ise ulusal literatürde çok sınırlı sayıdadır. Araştırma, öğretmenlerde pozitif psikolojik sermayenin ve tükenmişlikle ilişkisinin ortaya konulması açısından özgün görülmektedir.

\section{Kaynaklar}

Ali, N. \& Ali, A. (2014). The Mediating Effect of Job Satisfaction between Psychological Capital and Job Burnout of Pakistani Nurses. Pakistan Journal of Commerce and Social Sciences, 8 (2), 399-412.

Aliyev, R. \& Tunc, E. (2015). Self-efficacy in counseling: The role of organizational psychological capital, job satisfaction, and burnout. Procedia-Social and Behavioral Sciences, 190, 97-105. 
Avey, J. B.,Luthans, F., \&Jensen, S. M. (2009). Psychological capital: A Positive resource for combating employee stress and turnover. Human Resource management, 48(5), 677-693.

Büyüköztürk, Ş., Çakmak, E., Akgün, Ö.E. Karadeniz, Ş., Demirel, F. (2014). Bilimsel Araştırma Yöntemleri. Ankara: Pegem A Yayıncılık.

Caprara, G. V.,\& Cervone, D. (2003). A Conception Of Personality for A Psychology Of Humanstrengths: Personality As An Agentic, Self-Regulating system.

Cheung, F., Tang, C. S. K., \& Tang, S. (2011). Psychological capital as a moderator between emotional labor, burnout, and job satisfaction among school teachers in China. International Journal of Stress Management, 18(4), 348.

Çelikkaleli, Ö. (2011). Yetişkin eğitimcisi öğretmenlerin tükenmişlik ve mesleki yetkinliklerinin incelenmesi. Mehmet Akif Ersoy Üniversitesi Sosyal Bilimler Enstitüsü Dergisi. (4), 38-53.

Çetin, F. \& Basım, H. N. (2012). Örgütsel psikolojik sermaye: bir ölçek uyarlama çalışması. Amme İdaresi Dergisi, Cilt 45,1, 121-137.

Çetin, F., Şeşen, H. \& Basım, H. N. (2013). Örgütsel Psikolojik Sermayenin Tükenmişlik Sürecine Etkileri: Kamu Sektöründe Bir Araştırma. Anadolu University Journal of Social Sciences, 13(3).

Dolunay, A. B. (2001). Keçiören İlçesi “Genel Liseler Ve Teknik-Ticaret-Meslek Liselerinde Görevli Öğretmenlerde Tükenmişlik Durumu” Araştırması.

Ergin, C. (1992). Doktor ve Hemşirelerde Tükenmişlik ve Maslach Tükenmişlik Ölçeği’nin Uyarlanması. 7. Ulusal Psikoloji Kongresi Bilimsel Çalışmaları.

Ergül, H. F., Saygın, S., Tösten, R. (2013). Sınıf Öğretmenlerinin Tükenmişlik Düzeylerinin Çeşitli Değişkenler Açısından İncelenmesi. Elektronik Dicle Üniversitesi Sosyal Bilimler Enstitüsü Dergisi. 5,10.

Erkuş, A., Fındıklı, M. A. (2013). Psikolojik Sermayenin İş Tatmini, İş Performansı ve İşten Ayrılma Niyeti Üzerindeki Etkisine Yönelik Bir Araştırma. İstanbul Üniversitesi İşletme Fakültesi Dergisi. Cilt/Vol:42, Say1/No:2, 2013, 302-318

Freudenberger, H.J. (1974). Staff Burnout. Journal of Social Issues, 30, 159-65.

Gillert, J. E. (2014). The Relationship of Psychological Capital And Burnout With Training and Peformance. Doctoral Dissertation. University of Oklahoma.

Hefferon, K.,\&Boniwell, I. (2014). Pozitif Psikoloji: Kuram, Araştırma Ve Uygulamalar. T. Doğan, \& G. Ekici (Eds.). 
Herbert, M. (2011). An exploration of the relationships between psychological capital (hope, optimism, self-efficacy, resilience), occupational stress, burnout and employee engagement. Doctoral dissertation. Stellenbosch: Stellenbosch University.

Kaya, A., Balay, R. \& Demirci, Z. (2014). Ortaöğretimde Görev Yapan Öğretmenlerin Psikolojik Sermaye Düzeylerinin İncelenmesi (Şanlıurfa İli Örneği). Electronic Journal of Social Sciences, 13(48).

Laschinger, H. K. S. \& Fida, R. (2014). New Nurses Burnout And Workplace Wellbeing: The İnfluence Of Authentic Leadership And Psychological Capital. Burnout Research, 1(1), 19-28.

Lin, T. L. (2013). The relationships among perceived organization support, psychological capital and Employees' Job burnout in international tourist hotels. Life SCI J, 10(3), 2104-2112.

Linley, P.A., Joseph, S., Harrington, S. \& Wood, A.M. (2006). Positive psychology: Past, present, and (possible) future. The Journal of Positive Psychology,1(1), 3-16.

Luthans F, Youssef C. M. \& Avolio B. J. (2007). Psychological Capital. New York: Oxford University Press.

Luthans, F., Avey, J.B., Avolio, B. J. \& Peterson, S. (2010). The development and resulting performance impact of positive psychological capital. Human Resource Development Quarterly, 21, 41-66.

Luthans, F., Avolio, B. J., Avey, J.B. (2007). Psychological Capital Questionnaire Self-Rater Form, Other Rater Form, Scoring Scale. Mind Garden, Inc.

Luthans, F., Vogelgesang, G.R. \& Lester, P.B. (2006). Developing the Psychological Capital of Resiliency. Human Resource Development Review, 5(1), 25-44.

Luthans, F.,Luthans, K. W., \&Luthans, B. C. (2004). Positive psychological capital: Beyond Human and social capital. Business Horizons, 47(1), 45-50.

Luthans, Fred. (2002). Positive Organizational Behavior: Developing and Managing Psychological Strengths. Academy of Management Executive.

Maslach, C. \& Jackson, S.E. (1981). The Measurement of Experienced Burnout. Journal of Occupational Behaviour.

Peng, J., Jiang, X., Zhang, J., Xiao, R., Song, Y., Feng, X. \& Miao, D. (2013). The impact of psychological capital on job burnout of Chinese nurses: The mediator role of organizational commitment. PloS one, 8(12), e84193.

Seligman, M. E. P. \& Csikszentmihalyi, M. (2000). Positive Psychology: An Introduction. American Psychologist, 55: 5-14. 
Seligman, M. E. P. (2002). Authentichappiness: Using The new positive psychology to realize. Your potential for lastingful fillment. New York: Free press.

Seligman, M.E.P. (1999). Positive social science. Journal of Positive Behavior Interventions, 1(3), 181-182.

Sılı̆̆g, A. (2003). Banka Çalışanlarının Tükenmişlik Düzeylerinin Çeşitli Değişkenler Açısından İncelenmesi. Yayınlanmamış Yüksek Lisans Tezi, Eskişehir Anadolu Üniversitesi Ĕ̆itim Bilimleri Enstitüsü, Eskişehir.

Silah, M., Endüstride Çalışma Psikolojisi, Sistem Yayıncılık, Ankara, 2005

Sykes, A. O. (1993) . An Introduction to Regression Analysis. The Inaugural Coase Lecture. University of Chicago Law School, Chicago. http://chicagounbound.uchicago.edu/cgi/viewcontent.cgi?article=1050\&context=law and economics Erişim Tarihi: 31.03.2017

Tettegah, S. (2002). Teachers, İdentity, Psychological capital and electronically mediated representations Of Cultural consciousness. In Proceedings Of The 14th Ed-Media World Conference On Educational Multimedia, Hypermedia and telecommunications (Pp. 100101).

Tösten, R. (2015). Öğretmenlerin Pozitif Psikolojik Sermayelerine İlişkin Algllarının İncelenmesi. Yayımlanmamış Doktora Tezi. Gaziantep Üniversitesi Eğitim Bilimleri Enstitüsü

Wang, Y., Liu, L., Wang, J., \& Wang, L. (2012). Work-family conflict and burnout among Chinese doctors: the mediating role of psychological capital. Journal of occupational health, 54(3), 232-240.

Yang, M. H., Yeh, C. T., Yang, H. W., \& Mui, W. C. (2013). The impacts of perceived organizational support and psychological capital on sport burnout of junior high school physical education students. Life Science Journal, 10(3), 1946-1956.

Yıldırım, M. H.,\&İçerli, L. (2010). Tükenmişlik Sendromu: Maslach Ve Kopenhag Tükenmişlik Ölçeklerinin Karşılaştırmalı Analizi. Organizasyon Ve Yönetim Bilimleri Dergisi, 2(1).

Yıldırım, S. (2007). Anaokulu Öğretmenlerinde Tükenmişlik Düzeyi Ve Umutsuzluk Düzeyleri Arasındaki İlişki. Yayımlanmamış Yükseklisans Tezi, Yeditepe Üniversitesi Sosyal Bilimler Enstitüsü, İstanbul.

Zhao, Z.,\&Hou, J. (2009). Thestudy On Psychological capital development Of İntrapreneurial team. International Journal Of Psychological studies, 1(2), 35. 